\title{
Beyond Pre/Post Measurement: \\ Discourse Analysis as an Alternative Methodology in Reporting on an Intervention Programme
}

\author{
Teguh Wijaya Mulya \\ Faculty of Psychology \\ Universitas Surabaya
}

\begin{abstract}
Pre/post comparison has become the most prominent method in reporting on a psychological intervention programme, to the extent that it is almost impossible to report on such programmes without a pre/post evaluation framework. This article introduces discourse analysis methodology as an alternative in reporting on an intervention programme, highlights some of its benefits, and provides an empirical example of its application. Discourse analysis methodology is applied to analyze a diversity workshop, conducted by the author, in a youth refuge in Surabaya $(N=15)$. Three key discourses were identified, namely, a discourse of (different) abilities, a discourse of peaceful resolution, and a discourse of crime as a natural consequence of inequality; which are discussed in relation to the methodological benefits of the application of discourse analysis, in an intervention programme.
\end{abstract}

Keywords: discourse analysis, pre/post measurement, psychological intervention programme

Perbandingan pra/pasca telah menjadi metode paling dominan dalam melaporkan program intervensi psikologis, dominansinya mencapai taraf hampir mustahil untuk melaporkan program intervensi tanpa menggunakan evaluasi pra/pasca. Artikel ini memperkenalkan metodologi analisis wacana sebagai sebuah alternatif dalam melaporkan program intervensi, menyoroti beberapa keuntungannya, dan memberikan contoh aplikasinya secara empiris. Metodologi analisis wacana diterapkan untuk menganalisis sebuah lokakarya kebhinekaan yang dilakukan oleh peneliti untuk remaja rumah singgah di Surabaya $(N=15)$. Tiga wacana kunci berhasil diidentifikasi, yaitu, wacana kemampuan yang berbeda, wacana resolusi damai, dan wacana kriminalitas sebagai konsekuensi alami kesenjangan. Ketiganya didiskusikan dalam kaitannya dengan keuntungan metodologis analisis wacana untuk program intervensi.

Kata kunci: analisis wacana, pengukuran pra/pasca, program intervensi psikologis

Psychological research generally reports on the effectiveness of an intervention programme by comparing the results of the pre- and post-tests (for example, Thompson-Brenner, Boswell, Espel-Huynh, Brooks, $\&$ Lowe, 2018). This pre/post method has been considerably dominant within the field; it is almost impossible to think about an intervention programme without using such framework. This article aims to offer a methodological alternative to reporting on an intervention programme beyond the pre-post comparison method, namely, a discourse analysis methodology. In addition to exploring the ways in which discourse analysis might be beneficial for reporting an interven-

Correspondence concerning this article should be addressed to Teguh Wijaya Mulya, Faculty of Psychology, Universitas Surabaya Jalan Raya Rungkut Mejoyo (Kalirungkut), Surabaya 60293. E-mail: teguh@staff. ubaya.ac.id tion programme, the article also provides an example of the application of discourse analysis in a specific intervention programme, in order to illustrate how this relatively new methodology may be applied empirically.

The article begins with a brief theoretical discussion on discourse theory, discursive psychology, and the benefits of using discourse analysis in examining psychological intervention programmes. Subsequently, a specific intervention programme conducted by the author is described and analyzed, using discourse analysis. The findings of the discourse analysis are presented and discussed, particularly in relation to its methodological benefits.

While there are various discourse theories available within this field of scholarship, my approach to discourse is informed by feminist post-structuralist 
theories (Davies, 1991; Weedon, 1987). This group of feminists has applied and (re)appropriated Michel Foucault's $(1972,1978)$ theorization of power, discourse, and resistance to gender analyses; which, in the opinion of the author, might be quite accessible for psychological researchers. As opposed to the traditional understanding of power, where society was controlled using force and domination, Foucault (1978) redefined power as impersonal (not belonging to anyone), relational (can be exercised only in social relations), and productive (both enabling and constraining). It is not always oppressive in a traditional sense, because it (re)produces docile individuals, who comply willingly. To this end, willing compliance, power operates by governing knowledge within society, particularly through the circulation of discourses.

A discourse is a set of interconnected ideas, through which individuals give meaning to their experiences. Discourse is always context-specific, multiple, shifting, contested, and related to the operation of power (Weedon, 1987). For instance, psychology, as a discourse, has enabled individuals to understand human behaviors as being governed by certain principles or laws, from operant conditioning to evolutionary mechanisms. This way of giving meaning to human behaviors originates, and exists, in a specific cultural and historical situation, namely, Western modern scientific tradition. Throughout history, and across cultures, there have been various other ways of understanding human behaviors, which may compete with those of psychology. Even within psychology itself, there has been a succession of prominent theories, some of which might now be considered inaccurate. What is not usually discussed in psychology is the operation of power implicit within this ostensibly objective science of human behavior, such as the pathologization of same-sex sexuality in the past, which has marginalized gay men, lesbians, and bisexuals. In this case, psychology might have become an apparatus of power, to govern, control, and even oppress certain groups in modern society.

Using discourse theory to understand social relations always implies the possibility of resistance (Weedon, 1987). It is precisely within the shifting nature of discursive formations that the possibilities of resistance lie. Dominant discourse, which usually presents itself as natural or commonsensical, can always be challenged, destabilized, or reworked. Alternative discourses, which are marginalized, always have the potential to gain more currency, and even to replace the dominant ones. Resistance, therefore, involves efforts to identify, draw upon, and circulate, alternative discourses.
The author's previous work, for example, has identified alternative sexual discourses, drawn upon by Indonesian youth, which may contest the dominant discourse of sexual morality (WijayaMulya, 2018).

Although still profoundly under-represented, discourse theories have increasingly permeated the field of psychology in the last 30 years, and the term 'discursive psychology' has been coined. The book by Henriques, Hollway, Urwin, Venn, and Walkerdine (1984), "Changing the subject: Psychology, social regulation, and subjectivity", and another by Potter and Wetherell (1987), "Discourse and social psychology: Beyond attitudes and behaviours", are considered to be the earliest psychological works, based on discourse theory. Since then, book chapters on discursive psychology have appeared several times, in edited collections on critical psychology, from chapters by Ian Parker in 1997 to Margaret Wetherell in 2015. Carla Willig (2013) has also included a chapter on discursive psychology, as a research method, in her methodology book. Today, a number of books specifically dedicated to the discussion of discursive psychology are readily available, such as that by Sally Wiggins (2016). Most of these works have criticized the individualized analyses of mainstream psychology, and demonstrated how psychological phenomena are discursively constituted through language, within specific socio-political-historical contexts. The researchers applied discourse analysis, a methodology which focuses on the identification of discourses which have given rise to individuals' understanding of their worlds, the consequences of their drawing on those discourses, and the possibilities of destabilizing the dominant discourses (Willig, 2013).

This article affiliates with, and extends, the work of these scholars, by taking discourse analysis into the reporting of a psychological intervention programme, which - to the best of the author's knowledge - has not previously been done. Existing psychological studies have employed discourse analysis to examine the qualitative data generated from everyday conversation contexts (for example, Kitzinger, 2005) and interview or group discussion contexts (for example, Augoustinos, Tuffin, \& Rapley, 1999); but not from any intervention context. As also noted elsewhere (WijayaMulya \& Aditomo, 2018, advanced online publication), it is argued that using discourse analysis in this context may have several benefits, as compared to traditional pre/post evaluations. Firstly, discourse analysis offers a more contextual view of the topic studied, as compared to mainstream psychology's post-positivist paradigm (Creswell \& Poth, 2018), which is generally pre- 
dicated upon the belief of a relatively universal mechanism governing human behavior. Owing to the contextual nature of discursive formation, discourse analysis must always be conducted with a full awareness of the contextuality of the participants, the data, and the findings. Secondly, discourse analysis provides more complex, and deeper, insights into how individuals construct their knowledge about a phenomenon, particularly the "logic" (that is, discourse) they use to understand it, which is often not revealed in pre/post questionnaires. By identifying these "logics", (further) intervention may be tailored, specifically to challenge the dominant ways of thinking in the communities studied, and to circulate alternative discourses, which are comprehensible, or "make sense", to them. Thirdly, discourse analysis lends participants a better sense of agency, as it does not simply ask participants to respond to a pre-coded set of questions. Instead, it focuses on the "own" ways of thinking of the participants, about the phenomenon, and, subsequently, unearths dominant/ alternative discourses giving rise to those ways of thinking.

As with other qualitative researchers, discourse analysts generally do not make any prediction regarding the findings of their studies, because these are genuinely dependent upon the participants, their contextual experiences, and the data construction process. Participants are not merely the "target" of the psychological intervention, expected to change in a particular manner after the programme. Rather, participants are partners, co-researchers, who co-construct possibilities for change and transformation, in open-ended ways. These potential benefits will be empirically discussed further, in the example below of the application of discourse analysis in an intervention programme. Prior to that, the methods and the programme will be detailed in the sections following.

\section{Method}

\section{Overview of the Programme}

The intervention programme was a community development (pengabdian pada masyarakat) programme, funded by the Indonesian Ministry of Research, Technology, and Higher Education, through the Community Partnership Programme (Program Kemitraan Masyarakat) scheme. The author was the principal investigator of the project, applied for funding in mid2017 , received a grant in early 2018, and implemented the programme in mid-2018. The programme part- nered with a youth refuge (rumah singgah) in Surabaya, which provides scholarships and accommodation for marginalized youth. There were two major components to the programme. The first was a sub-programme of entrepreneurship training, focused on three different skills, namely, multi-media/design skills, sewing skills, and make up/hair-styling skills. The second was a diversity workshop, aimed at building tolerance, empathy, and social awareness within these youths, in three contexts, namely, "diffability" (a newly coined term, intended to emphasize that so-called 'disabled' people are not actually disabled, but rather have different abilities to the norm), religious diversity, and socio-economic inequality. These three contexts were chosen based on preliminary discussions with the leader of the shelter, related to the needs of the youth. This article analyses, and reports on, the second part of the programme, that is, the diversity workshop.

\section{Procedure}

The diversity workshop was conducted on Saturday, 11 September 2018, from 9 a.m. to 4 p.m., at the shelter premises. Beside a formal introduction and a "breaking the ice" session, the workshop consisted principally of four sessions. The first three sessions involved an introduction to the topics (definitions, types, and so on), the screening of short films, small group discussions, and a class discussion. The films were Wonder (Lieberman, Hoberman, \& Chbosky, 2017) for the session on diffability, which told the story of a boy with a rare facial condition, who was bullied, but who also made friendships, at school; Ahu Parmalim (Herdiany \& Maharani, 2017), for the session on religious diversity, a documentary about a youth who is a member of a traditional religion, "Parmalim"; and, for the session on inequality, Alangkah Lucunya Negeri Ini (Zain \& Mizwar, 2010), a drama-comedy film about a group of poor children working as pickpockets, and three university graduates who try to help them build a better life. Small group (4-6 persons, randomly assigned) discussions were conducted after each film, guided by a set of questions, such as, "how do you feel if you/someone you love is diffabled/poor/a member of a marginalized religion?", "what should society do to address diffability, religious diversity, and inequality?", and, "what can you do, as a youth, to improve the conditions of poverty/religious intolerance/discrimination against people with a diffability?". Each group then shared the results of their discussions with the other groups. The last session asked the participants (in groups) to create a public service advertisement 
(iklan layanan masyarakat), to perform and record it, using a mobile-phone camera, and to screen it for the entire three groups. For the video-making, the groups negotiated and assigned the three topics themselves. At the end of the workshop, participants wrote a short reflection on what they had learned from the workshop.

This workshop was designed on the basis of several theoretical deliberations. Firstly, it followed the findings of previous studies (Berger, Benatov, AbuRaiya, \& Tadmor, 2016), which showed that the provision of information about specific groups, in a positive atmosphere, increases understanding and tolerance towards those groups. During the introduction to the topics, in each session, participants acknowledged that the information provided was quite new to them, for example, the various types of physical and mental diffabilities. Secondly, previous studies have found that perspective-taking is one of the most useful cognitive activities, which may foster tolerance and empathy (Schweitzer, 2017). The films, and the questions in the group discussion, were chosen and designed to help participants take the perspective of the marginalized groups, such as in the question "how do you feel if you/someone you love is diffabled/poor/ a member of a marginalized religion?" Thirdly, it is thought that involvement in activism for a cause, or for a marginalized group, may positively enhance attitudes towards that cause or group (Bem, 1967). Creating a public service advertisement opposing the bullying of a diffabled person, for example, might reduce the likelihood of the creators themselves engaging in bullying. In using these three theoretical deliberations, and their applications in the workshop, it was hoped that participants were not directed towards a uniform change, measurable in a continuum; but rather, that they should think about, reflect on, discuss, and create artworks which were reasonably open-ended, about the issue of diversity, tolerance, and empathy. In so doing, participants were positioned not merely as the targets of the intervention, but also as agents of change, whose thoughts were given attention, and who were capable of self-transformation.

\section{Participants}

The participants were 15 youths (eight females, seven males) aged 14 to 20 years old, who were living in the shelter when the workshop was conducted. 14 youths were studying in senior high school, and one in junior high school. Almost all of them were from a rural village in South Malang, with one originating from Maluku. Most of them had lived in the shelter for from between one and three years. They signed informed consent forms at the beginning of the workshop, after receiving an explanation of the meaning of such forms, and were given an opportunity to ask questions. The confidentiality of their identities was strictly maintained.

\section{Data Construction and Analysis}

The main sources of data in the current analysis were public service advertisements created by the participants, small group discussion worksheets, and individual reflections about what had been learned at the workshop. These data were analyzed qualitatively, using discourse analysis (Willig, 2013), by which the author reviewed/read them repeatedly, and sought the key discourses, or underlying ideas, drawn upon by the participants. More specifically, the analysis paid attention to alternative discourses, or "logic", within the data, which might destabilize or challenge the dominant discourse of religious intolerance, the normalization of bullying against people with diffabilities, and the acceptance of socio-economic inequality in the Indonesian context.

\section{Findings and Discussion}

Three alternative discourses identified in the data are discussed in this section, namely, a discourse of (different) ability, a discourse of peaceful resolution, and a discourse of crime as natural consequences of inequality. The discussions focus on how these discourses were drawn upon by participants in creating the advertisements, are contextually relevant with and have potentials to destabilize particular dominant discourses in contemporary Indonesia, and what methodological benefits are offered by such analyses. Each of these discourses will be elaborated upon in the sections following.

\section{A Discourse of (Different) Ability}

The public service advertisement created by participants, related to the issue of diffability, displays a story of a young blind person and a bully. The film begins with the bully on his bicycle, mocking and pushing the blind youth until he falls to the ground. The bully then plays with a friend, who is learning to play a guitar. The bully also wants to learn to play a guitar, so the guitar student takes him to the house 


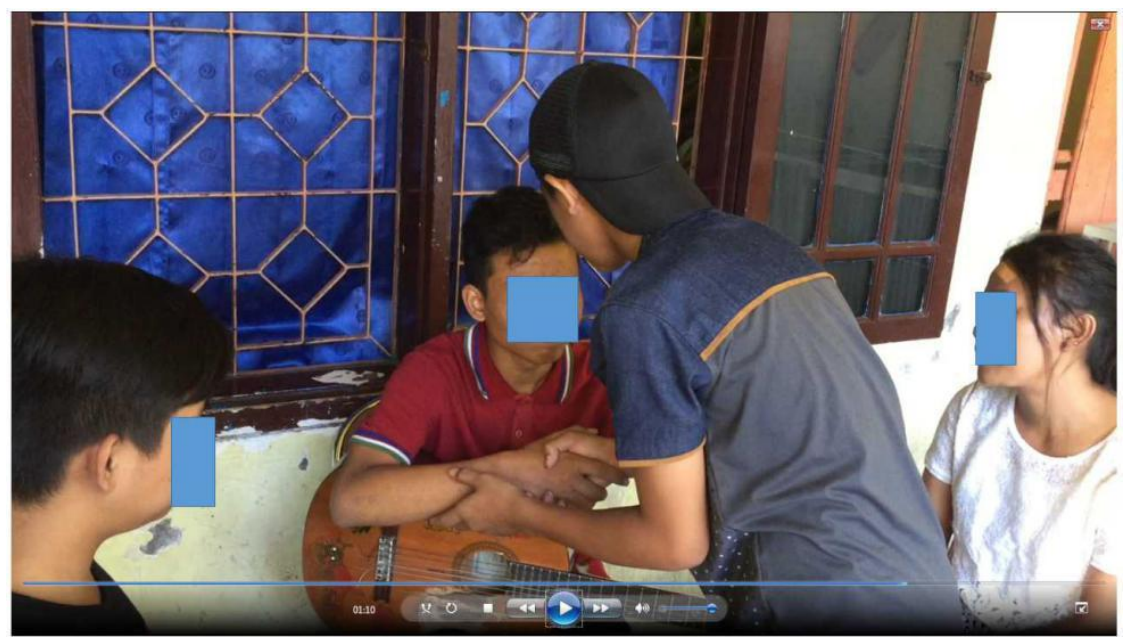

Figure 1. A screenshot from the participants' public service advertisement, where the bully apologizes to the blind person.

of a friend of his, who can play guitar very well and has generously taught him to play the guitar. When he enters the house, the bully is surprised, because the one who can play the guitar very well is the blind person he previously pushed to the ground. The bully then apologizes, and realizes that he should not undermine people with diffability, because they may have other abilities he does not possess. The scene of the public service advertisement is shown in Figure 1.

The participants creating this advertisement positioned people with diffabilities through a discourse of ability, wherein it is believed that everyone has unique abilities. This is precisely the discourse which gives rise to the replacement of the term "disability" with "diffability", promoted by both Indonesian and international activists (for example, Suharto, Kuipers, $\&$ Dorsett, 2016). The person is no longer discursively positioned as "disabled" or lacking in certain abilities, and therefore in need of external help; instead, he or she is positioned as being able, but in a different way, or differently able. For instance, a blind person may be unable to see, but he or she may have very sensitive ears, compared to those of the average person. In this way, the potential of persons with diffabilities is emphasized, not their deficiencies.

Identifying how this "logic" has been taken up by participants might be beneficial in a number of ways. Firstly, it captures how participants engaged with the issues, or to be more precise, how they constructed their thinking about the issues. It is a more "direct" constructivist understanding about the way these youths think, as compared to that of mainstream quantitative research, which generally examines external factors/variables influencing attitudes and behaviors.
Secondly, such analysis also portrays a more contextual dynamic, that is, what "logic" is accepted by participants in this context. A discourse on human rights, for example, might be common among international studies and activist forums on diffability (Stein, 2015) but it might not be so dominant amongst these youths, very probably because awareness about human rights in Indonesia is, in general, still low.

The advertisement ends with a sheet of paper displayed to the camera, bearing the powerful message shown in Figure 2.

\section{A Discourse of Peaceful Resolution}

The group creating the public service advertisement for the issue of religious diversity decided to stage a play about two persons, from two different religions, fighting with each other. It started with a male actor sitting and praying, and then a female actor ignorantly walked in front of him. The male actor felt offended, and immediately scolded her, and pushed her shoulder. The female actor did not say anything about her walking past, but she protested about him pushing her, and pushed his shoulder in return. All other members of the group (wearing clothes/symbols from different religions) then gathered and helped them resolve the conflict. After listening to both sides, the group representing various religions asked them to apologize to each other for their misunderstandings. The advertisement ended with them all delivering a message of religious tolerance. The scene of the public service advertisement is shown in Figure 3.

This scene is a textbook case scene of conflict resolution, commonly taught to Indonesian school child- 


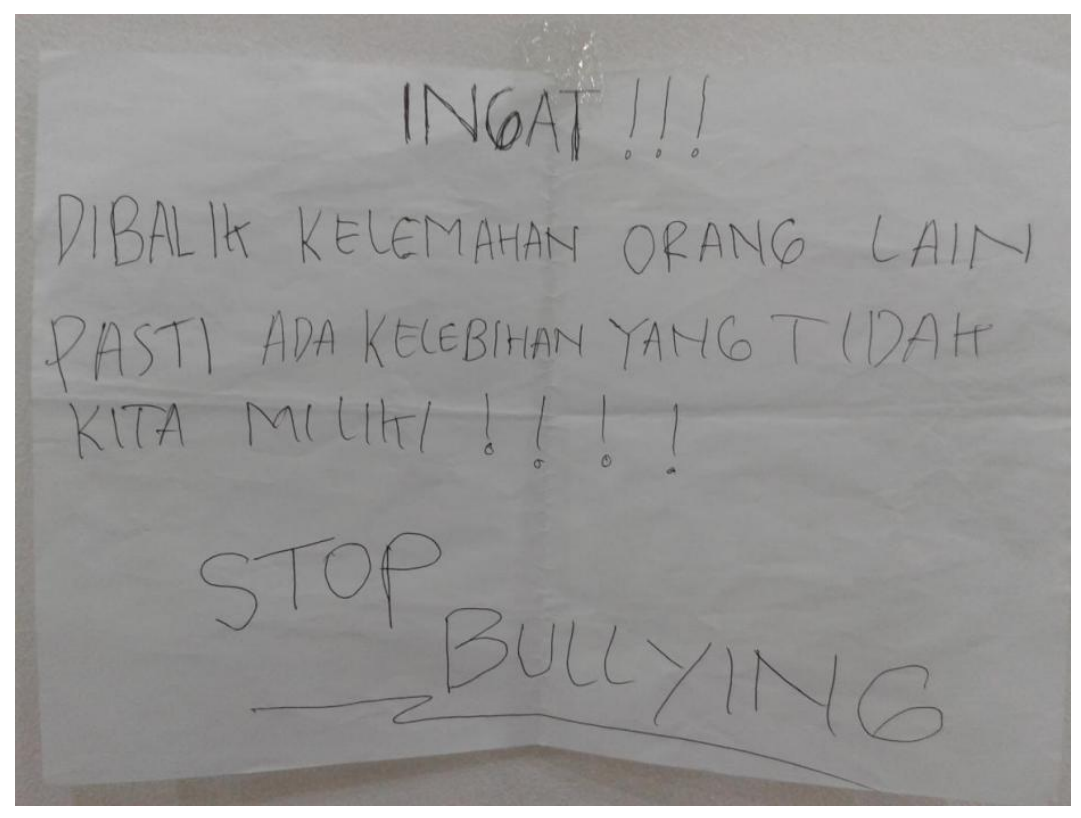

Figure 2. A document shown on camera at the end of the film, which says: "Remember! Behind a person's weakness there is surely a specialty we don't have!!! Stop bullying."

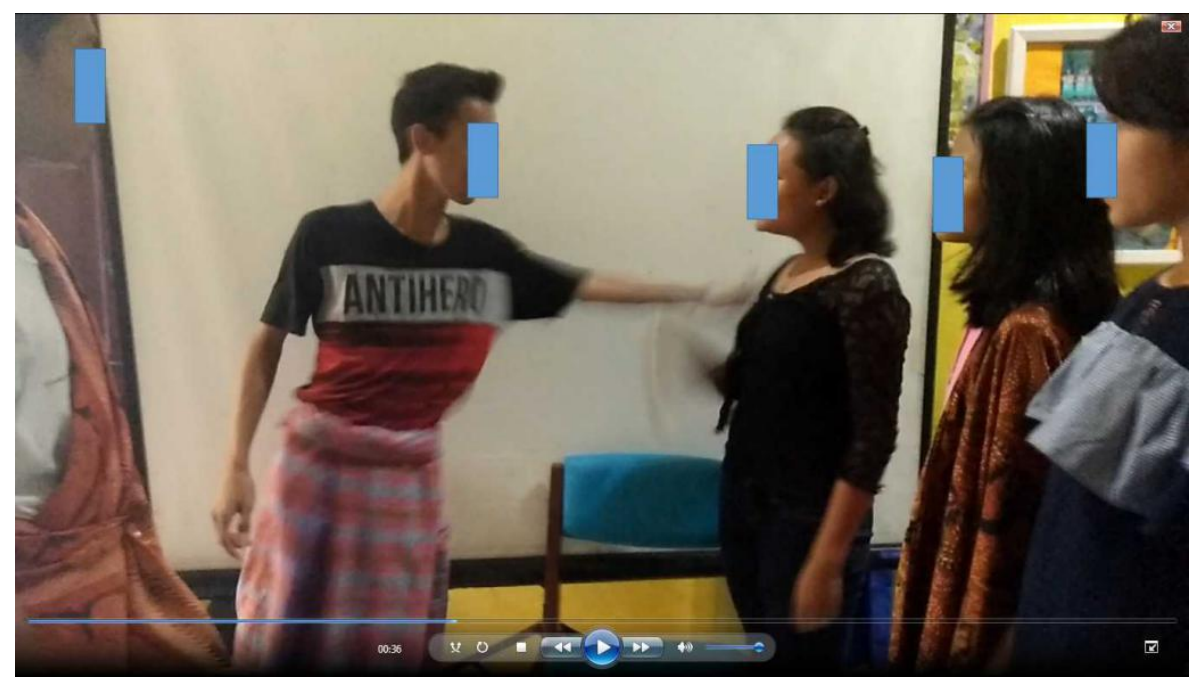

Figure 3. A screenshot from the public service advertisement on religious tolerance, created by participants.

ren. Its theme is that whenever one sees conflict, one must help to resolve it, by talking peacefully (as opposed to fighting physically), listening to both sides, and asking each party to apologize to the other, as both may well have engaged in a form of misconduct, during the conflict. Quite often, "protecting our unity"/ "menjaga persatuan" (as written in a participant's reflection) was added as the main reason for forgiving each other. This term is usually associated with the third principle in the Pancasila (Indonesia's state ideology), which proclaims "The Unity of Indonesia"
("Persatuan Indonesia"). Sadly, such peaceful ways of resolving conflict (that is, by talking, as fellow Indonesians) has recently been superseded by other nonpeaceful means. For instance, during the time period of the analysis of this data, there was a case of "religious defamation" (penistaan agama) in which a Buddhist woman named Meiliana was sentenced to an 18month term of imprisonment, for asking a question of her neighbor, as to why the calls on the loudspeaker of the nearby mosque had recently been getting louder (BBC Indonesia, 2018, August 22). Before her sen- 
tencing, the local residents reacted to her question by attempting to burn down her house, and by attacking six Buddhist temples in her town. Some people involved in the riot were arrested, but sentenced to only one to five months in gaol. Legal action, violence, and arson committed against houses or places of worship have been chosen in answer to religious conflict, not peaceful talk. The juxtaposing of the Meiliana case with this simple, normative, "everyone-should-know" discourse of peaceful resolution, drawn upon by the participants in their advertisement, should be an alarming reminder about the current situation in Indonesian society.

Using discourse analysis to examine this data not only does not deny the unavoidability of discussions about the contextuality of the data (that is, Indonesian contemporary contexts), but also lends the participants more space to exercise agency, as co-researchers or co-constructors of the data. Their choices regarding genre, plot, scenes, and their ways of thinking about the issue, are what are prioritized, not the presumptions of the researchers, expressed in pre-coded measurements. In this way, discourse analysis is faithful to its commitment to respect the agency of participants to build a more equal and collaborative researcherparticipant relationship.

\section{A Discourse of Crime as a Natural Consequence of Inequality}

The final discourse identified in this analysis is identified in the public service advertisement on the issue of socio-economic inequality created by participants.
The advertisement depicts a scene in which a female pedestrian stops by a sad-faced beggar and gives him some coins. As she continues her walk, a bag-snatcher (penjambret) observes her and then snatches her handbag and runs away. The advertisement ends with two participants delivering a message about social inequality, and about caring for each other in society ("kepedulian sosial"). They explain that in a society where inequality is high, it is not only poverty which increases (represented by the beggar) but also crime (represented by the bag-snatcher). The scene of the public service advertisement is shown in Figure 4.

In spreading awareness about socio-economic inequality, the creators of this advertisement drew on a discourse which positioned crime as a natural consequence of inequality. If the poor have no means to survive financially (for example, no access to the job market), they might have no other way to survive than by resorting to crime, to feed their families. Such logic also prevailed in the small discussion worksheets, wherein they discussed how it feels to be poor: "Sedih, susah, banyak memikirkan untuk berbuat jahat, contohnya mencopet, maling" ("Sad, in difficulties, I have often thought about engaging in crime, such as pickpocketing, stealing." Another group wrote that being poor makes people tend to "justify anything" ("menghalalkan segala cara") to obtain money. Such a discourse may, or may not, correspond with the realities of the poor in Indonesia (that is, their moral decisions), but this is not the object of the current analysis. In this analysis the focus is on how this discourse has been taken for granted, and perceived as effective, by the creators, to convince the audience to start thinking and

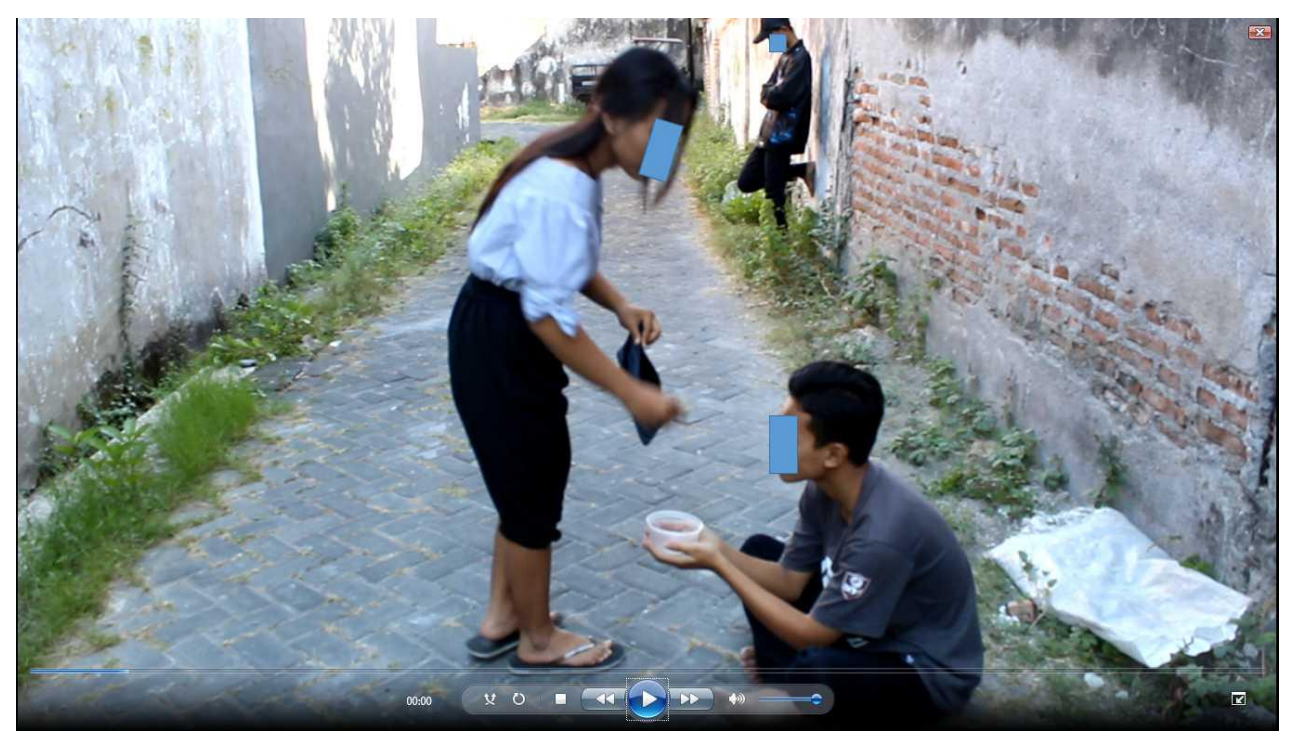

Figure 4. A screen shot from the public service advertisement on social/economic inequality. 
caring for the poor. This discourse could indeed be effective, as it may incite fear in the upper-middle class audience. It indirectly justifies crimes committed by the poor in a highly unequal society, such as that in Indonesia. Drawing on this discourse has enabled the creators of this advertisement to circumvent the victim-blaming logic dominant amongst the Indonesian middle class, where the poor are positioned as lazy, and responsible for their own unfortunate conditions. The participant identification with the poor is very likely based on their own social position, or family backgrounds, which had resulted in them having to live in the shelter at the time of the workshop. One participant, who presented the result of his small group discussion to the class, took a brief emotional pause when talking about how it feels to be poor, demonstrating that what he said might be something very close to his own personal experiences.

As compared to quantitative-based pre/post measurement, discourse analysis (and other qualitative research methodology in general) is much more powerful in exploring the complexity, or the emotionality, within the data and the research process. A display of emotionally moving narratives, for example, may touch the hearts of the readers, and may incline people to act in support of social transformation.

\section{Limitations}

There are several limitations to the current study. Firstly, this version of discourse analysis is limited to a feminist poststructuralist version of the Foucauldian discourse analysis. There are various other versions of discourse analysis, which may differ slightly. Secondly, the contextual nature of the discourse analysis in this study might limit the possibility of applying these findings in other relevant contexts. Thirdly, discourse analysis, as a methodology, has its own limitations, owing to its specific onto-epistemo-methodological positions, including how generally accepted methodological questions in mainstream psychology (for example, generalizability, objectivity, and control over extraneous variables) may become irrelevant.

\section{Conclusion}

This article has introduced and argued for the potential benefit of using discourse analysis methodology in reporting on an intervention programme. Discourse analysis may provide several benefits, including a more contextual and nuanced examinations of the topic studied, better understanding of how indi- viduals construct their experiences, and a more respectful approach to the agency of participants. The article has also provided an example of how discourse analysis can be applied to analyze and report on an intervention programme (that is, a diversity workshop) conducted by the author. Three discourses have been identified and discussed, namely, a discourse of (different) ability, a discourse of peaceful resolution, and a discourse of crime as a natural consequence of inequality.

The implications of the study may be elaborated as follows. Firstly, considering the benefits it may provide, future psychology researchers may care to utilize discourse analysis in reporting on intervention programmes, or to complement their traditional pre/ post evaluations. Secondly, it is important to note that, in implementing discourse analysis in such studies, there may be a glaring discrepancy in conceptualizing "effectiveness" or "improvement", which may need to be reconciled, particularly with the funders and other interested parties. In the example discussed above, for example, the effectiveness of the intervention is understood in terms of the creation of possibilities for discursive contestation (that is, challenging the dominant ways of understanding specific issue), rather than in those of the change in individual responses to a precoded pre/post measurement. Such paradigmatic tensions may need to be negotiated carefully, before a decision is made to use discourse analysis.

\section{References}

Augoustinos, M., Tuffin, K., \& Rapley, M. (1999). Genocide or a failure to gel? Racism, history and nationalism in Australian talk. Discourse \& Society, 10(3), 351-378. https://doi.org/10.1177/09579265 99010003004

BBC Indonesia. (2018, August 22). Dipertanyakan, vonis 18 bulan penjara bagi Meiliana yang keluhkan volume azan. Retrieved from: http://www.bbc. com/indonesia/amp/indonesia-45271624

Bem, D. J. (1967). Self-perception: An alternative interpretation of cognitive dissonance phenomena. Psychological Review, 74, 183-200. https://doi.org/ 10.1037/h0024835

Berger, R., Benatov, J., Abu-Raiya, H., \& Tadmor, C. T. (2016). Reducing prejudice and promoting positive intergroup attitudes among elementaryschool children in the context of the Israeli-Palestinian conflict. Journal of School Psychology, 57, 53-72. https://doi.org/10.1016/j.jsp.2016.04.003 
Creswell, J. W., \& Poth, C. N. (2018). Qualitative inquiry and research design: Choosing among five approaches (4th ed.). Singapore: Sage.

Davies, B. (1991). The concept of agency: A feminist poststructuralist analysis. Social Analysis, 30, 42-53.

Foucault, M. (1972). The archaeology of knowledge and the discourse on language (A. M. S. Smith, Trans.). New York: Pantheon Books.

Foucault, M. (1978). The history of sexuality, vol. 1: The will to knowledge (R. Hurley, Trans.). New York: Pantheon Books.

Henriques, J., Hollway, W., Urwin, C., Venn, C., \& Walkerdine, V. (1984). Changing the subject: Psychology, social regulation and subjectivity. London: Methuen \& Co.

Herdiany, D. (Producer), \& Maharani, C. (Director). (2017). Ahu Parmalim [Motion picture]. Indonesia: Yayasan Kampung Halaman dan Yayasan TIFA.

Kitzinger, C. (2005). Heteronormativity in action: Reproducing the heterosexual nuclear family in afterhours medical calls. Social Problems, 52(4), 477498. https://doi.org/10.1525/sp.2005.52.4.477

Lieberman, T., \& Hoberman, D. (Producer), \& Chbosky, S. (Director). (2017). Wonder [Motion picture]. USA: Lionsgate.

Parker, I. (1997). Discursive psychology. In D. Fox, \& I. Prilleltensky (Eds.), Critical psychology: An introduction (pp. 284-298). London: Sage.

Potter, J. and Wetherell, M. (1987). Discourse and social psychology: Beyond attitudes and behaviour. London: Sage.

Schweitzer, F. (2017). Against religiously motivated violence: Religious education's contribution to peaceful relationships between different religions-What should it entail and how can it be evaluated? In E. Aslan \& M. Hermansen (Eds.), Religion and violence: Muslim and Christian theological and pedagogical reflections (pp. 207-225). Wiesbaden, Ger- many: Springer.

Stein, M. A. (2015). Disability human rights. In R. West (Ed.), Nussbaum and law (pp. 1-47). London: Routledge.

Suharto, S., Kuipers, P., \& Dorsett, P. (2016). Disability terminology and the emergence of 'diffability' in Indonesia. Disability \& Society, 31(5), 693712. https://doi.org/10.1080/09687599.2016.1200014

Thompson-Brenner, H., Boswell, J. F., Espel-Huynh, H., Brooks, G., \& Lowe, M. R. (2018). Implementation of transdiagnostic treatment for emotional disorders in residential eating disorder programs: A preliminary pre-post evaluation. Psychotherapy Research [Advanced online publication]. https://doi. org/10.1080/10503307.2018.1446563

Weedon, C. (1987). Feminist practice and poststructuralist theory. Oxford: Blackwell.

Wetherell, M. (2015) Discursive psychology: Key tenets, some splits, and two examples. In I. Parker (Ed.), Handbook of critical psychology (pp. 315324). New York: Routledge.

Wiggins, S. (2016). Discursive psychology: Theory, method, and applications. London: Sage.

WijayaMulya, T., \& Aditomo, A. (under review). Researching religious tolerance education using discourse analysis: A case study from Indonesia. British Journal of Religious Education.

WijayaMulya, T. (2018). From divine instruction to human invention: The constitution of Indonesian Christian young people's sexual subjectivities through the dominant discourse of sexual morality. Asian Studies Review, 42(1), 53-68. https://doi.org/10.10 80/10357823.2017.1407918

Willig, C. (2013). Introducing qualitative research in psychology. Berkshire: Open University Press.

Zain, Z. (Producer), \& Mizwar, D. (Director). (2010). Alangkah lucunya negeri ini [Motion picture]. Indonesia: Citra Sinema. 